used all over the world, and tho application of ultrasound has been advanced by Dr. Hughes practically and theoretically. Other subjects which he has investigated are the synthesis of pyridine nucleotides and coonzyme $\mathrm{A}$ in micro-organisms, the metabolism of polyphosphate and tho role of the cytoplasmic membrane in bacterial oxidations.

\section{Medical Research Council Clinical Pulmonary Physiology Research Unit}

THE Medical Research Council has established a Clinical Pulmonary Physiology Research Unit at King's College Hospital Medical School, London, under the parttime direction of Dr. P. Hugh-Jones. The Unit will be mainly concerned with the investigation of the changes caused by disease in the ventilation and blood flow to different parts of the lung.

\section{Australian School of Nuclear Technology}

AN Australian School of Nuclear Technology is to be established jointly by the Australian Atomic Energy Commission and the University of New South Wales at the Commission's Research Establishment at Lucas Heights. Control of the School will be vested in a board of five members, two nominated from the Commission and two from the University of Now South Wales, with one member nominated by the Australian Institute of Nuclear Science and Engineering. The aim of the School will be to promote formal training and education in nuclear technology and related topics. This will involve full-time courses of varying length in the science and technology of nuclear reactors, the production and application of radioisotopes, radiological safety and health physics, and siting and hazards evaluation of nuclear plants, and training courses for potential nuclear power station staff. Although the headquarters of the School will be at Lucas Heights, the School will use the facilities of both the Australian Atomic Energy Commission's Research Establishment and the University of New South Wales. The School will be open to students from overseas as well as from Australia. Enrolments are envisaged from the Commission's staff, universities, electricity authorities and industry, as well as from atomic energy organizations in New Zealand, South-east Asia and other areas. Lecturers for these courses will be drawn from the staff of the Commission, the University of New South Wales and other universities, other scientific research bodies, industry and learned societies. The first course is expected to commence in the second half of this year.

\section{Molecular Biology in the University of California}

A Department of Molecular Biology has been estab. lished in the University of California, Berkeley. Its initial staff will consist of the eloven members of the present Department of Virology (to be disestablished on July 1, 1964) and five additional professors from other depart. ments of the University. The Department offers an M.A. and a Ph.D. degree in molecular biology. Students may specialize in one or more of seven fields: ultrastructure, macromolecules, molecular and microbial genetics, cellular regulation and growth, biology of viruses and of bacteria, and bioenergenetics. Closely affiliated resoarch opportunities are afforded in the Virus Laboratory (Prof. W. M. Stanley, director) and in the Laboratory of Chemical Biodynamics (Prof. M. Calvin, director). The chairman of the now Department is Prof. Robley C. Williams.

\section{The Macaulay Institute for Soil Research}

"However important our other needs may be, the supply of food must come first. By far the groater part of our food comes from the soil. The importance of the study of that wide range of complex materials which we call simply soil is, therefore, paramount." These sentences are from the foreword by Sir William Slater to Volume 6 of Collected Papers, 1958-1960, and might be taken as the guiding principle of the work of the Macaulay Institute in augmenting our knowledge of the numerous factors concerned in plant nutrition (edited by Alexa M. B. Geddes and Rosaleen Noble. Pp. 24. Collected Papers Nos. 1-88. Craigiebuckler, Aberdeen: The Macaulay Institute for Soil Research, 1963). Eighty-eight papers that have appeared in scientific journals and a further eight titles are bound together, with an author index. They are contributions from the staff in the various major dopartments of pedology; soil survey; spectrochemistry; biochemistry; plant physiology; microbiology; and so:l fertility, and present a most satisfying pieture of the comprehensive character of the investigations completed or in progress. Such topics as mineralogy of silt and clay separates, dating of Carso clay, stimulation of leaf respiration, pollen analysis of peats, phosphate sorption and phosphate-dissolving bacteria, metabolism of chlorotic leaves, heavy metaj toxicity, natural and synthetic chelators, fertilizor placement, radioactive tracers in root development, trace element distribution and deficiencies and direct-roading spectrochemical methods are just a few selocted at random to illustrate the wide range of investigations concerned with the fundamental aspects of food production.

\section{Run-off Farming in the Negev Desert of Israel}

Dinapidated farm sites in desert areas are tostimony to the fact that food was once produced on ground that has long been regarded as barren. Ancient desert agriculture with a rainfall of about $100 \mathrm{~mm}$ depended on irrigation from catchment basins, by controlling run-off water during occasional floods. A report on the Avdat and Shivta Farm Projects, 1958-62, by Michael Evanari, Leslie Shannan and Naphtali H. Tadmor, describes the topographic and physiographic features of the region and the restoration of ancient farms by reconstruction of channels, for run-off from the hillsides, and of flooding systems (Pp. $143+12$ plates. Rehovot: The National and University Institute of Agriculture, 1963). Details are also given of soils, rainfall, temperature, humidity, infiltration depression and detention storage, and the report discusses the performance of many varieties of fruit trees and range crops. The watershed of the Shivta farm is typical of some 250,000 hectares of low parallel anticlines and undulating valleys; the farm had 5-6 inlets for run-off water and an elaborate system of water distribution to field terraces. Olives, plums, carobs, pomegranates, figs and apples have been easiest to establish. From the abundant remains in the Avdat region, two adjacent farms have been restored and a new distribution system constructed, with 14 terraces divided into plots; a total area of about 5 hectares of which half is under controlled experimental conditions. The development of apricots, cherries and peaches has been excellent; dry land seeding of range plants has proved to be impracticable; the establishment of artichokes and asparagus is promising.

\section{Radioactivity in Milk in the United Kingdom}

THE avorage ratio of strontium-90 to calcium in milk in the United Kingdom in 1963 was $26 \mathrm{pc} / \mathrm{g}$ (range $16-40 \mathrm{pc} . / \mathrm{g})$, or slightly more than twice the ratio for 1962 , according to the interim report (April-December 1963) of the Agricultural Research Radiobiological Laboratory, Wantage, Radioactivity in Milk, 1963 (ARCRL 11. Pp. vi + 16. London: Agricultural Research Council. Obtainable from H.M.S.O., 1964. $2 s .6 d$ net). The increase is due to the massive weapons testing programmes during the previous year. Information on other foods in 1963 is not yet complete, but the ratio of strontium-90 to calcium in milk is similar to that in the average total diet. Because dietary contamination was expected to increase during 1963, investigations were expanded at 'spocial sites' (mainly farms in sparsely populated areas) whero levels 